\section{Reflections on the Cultural Background to China's Reaction to the Nobel Prize Award}

Gunnar Haaland

\begin{abstract}
This paper deals with some complex and controversial issues that arose in connection with the 2010 Nobel Prize Peace award to the Chinese dissident Liu Xiao Bo. These issues involve different levels. On one level it is important not to confuse the Nobel committee's independence of outside interference from political and other organized agencies, with the question of whether the Nobel Prize committee's decisions can be ideological or politically unbiased in its decisions. Part of the strong Chinese reaction to the award is related to this issue. Another level deals with the Committee's widening of the criteria to be taken into account in the selection of candidates from the original criterion focused on direct contribution to reduction of armed conflicts, to the wider issues of indirect contributions like alleviation of poverty, ecological sustainability and most crucial the issue of human rights. The last issue is particularly critical since different states have different perspectives of what constitute human rights, and what rights should be given priority on different levels of the country's development. The main point of the article is to look at historical events and socio-cultural conditions that shape the Chine Government's (and many citizens') reaction to the 2010 award. This is placed in the context of the widening income differences emerging in the modern political economy of China and how these may affect the growth of civil society. The critical question is: will the reward contribute to promotion of civil society or will it lead to increased crackdown on dissident voices.
\end{abstract}

Keywords: 2010 Nobel Prize award, civil society in China, capitalization of power, China's dual economy
1. The ideas about universal human rights as expressed in Charter 08

According to Alfred Nobel's will, the Nobel Prize should be awarded to the person who has done the most or the best work for fraternity between nations, for the abolishment or reduction of standing armies, and for the holding and promotion of peace congresses. When we discuss China's reaction to the Nobel Prize Award for 2010, let's try to have different thoughts in our mind, e.g. with regard to respect for the values expressed in Charter 08; with regard to understanding conditions affecting the Chinese Government's reaction to the 2010 award; and with regard to possible consequences of the award for growth of civil society in China.

There are restrictions on circulation of information in China; there are restrictions on peoples' freedom to move; and there are restrictions on religious practice despite acceptance of various religious creeds. I have however no difficulty in understanding that there is resistance within the ruling Chinese Communist Party to movements that it perceives as challenges to its power. However, as I understand it, the Party is not as closed and unified as we are led to believe from western media. There seems to be different opinions within the party as manifested in Premier Wen Jiabao's plea for more tolerance of dissenting opinions and criticism (Minnie Chan, 2011).

When we discuss China's reaction to the Nobel Peace Price Award we should try to look into the following questions: Is there a growth of civil society in China that can exert some kind of influence on government rule, and is it likely that the 2010 year Nobel Prize Award will make the Chinese Government promote further developments of civil society. As I understand it, the Chinese Government's harsh reaction to Liu Xiao Bo was primarily based on their view that his involvement in formulation of Charter 08 was a criminal act according to Chinese Law.

Like most people in western countries I cherish the values expressed in the 19 demands formulated in Charter 08 (Charter 08: 2008) and I react to a verdict of 11 years of imprisonment for 
formulating them, although they may constitute a violation of Chinese Law. I think a main reason for the reaction is the following formulation: "In 1998 the Chinese government signed two important international human rights conventions; in 2004 it amended its constitution to include the phrase "respect and protect human rights"; and this year, 2008, it has promised to promote a "national human rights action plan." Unfortunately most of this political progress has extended no further than the paper on which it is written. The political reality, which is plain for anyone to see, is that China has many laws but no rule of law; it has a constitution but no constitutional government. The ruling elite continues to cling to its authoritarian power and fights off any move toward political change” (http://www.nybooks.com/articles/archives /2009 /Jan/15/chinas-charter-08/).

In principle it is not so difficult to agree that democratic reforms are desirable; the problem is the practicalities involved in implementing them. Social institutions are precarious, and we should keep in mind the danger of chaos when institutions are dismantled too fast. During Maoist rule institutions were set up to deal with the multiple problems of maintaining national unity, providing socio-economic equality, developing the forces of production, defending the country etc. These institutions were legitimated with reference to a rather utopian socialist ideology implemented by a totalitarian party. In a revolutionary situation people may find such utopian messages convincing and compelling. The problem arises in the post-revolutionary situation when a revolutionary government is faced with the problems of delivering its ideological promises-in terms of material gods as well as spiritual meaning. In China, policies based on these assumptions not only led to catastrophic human suffering and economic stagnation, but also to environmental degradation. The question is how to replace existing institutions with workable alternatives. Reforms can be drawn up by pen-strokes; to make them work is a different matter. That depends on both general beliefs in their legitimacy, and not the least on conditions affecting who will win and loose under changed rules. Change in legal rules in itself does not determine what kind of social order that will emerge. Our first task as social scientists is to explore the order and the tensions produced in the existing institutional set-ups and then try to anticipate processes that may affect the way they are "moving”. European history over the last 80 years clearly demonstrate the difficulties of establishing workable "democratic institutions" that also protects "human rights" as defined in western cultural traditions. Although the idea of democracy expressed in elections to political assemblies and positions may be widely accepted by the elites in Afro-Asian countries, experience shows that in practice it has not only been difficult to implement them, but also that there are many cases (e.g. Sri Lanka, Nepal, Bangladesh, Sudan) where it may be argued that their introduction had disastrous affects on the Human Right situation. The amazing example of success is of course India, and a contributing factor here may be the fact that Hindu caste ideology so far has served as an integrating ideology (a paradox from a Human Right perspective). My point is that democracy and Human rights should be seen in wider contexts of socio-cultural developments, most importantly conditions promoting the growth of civil society.

\section{Is the Nobel Committee unbiased?}

First I would first like to make a comment on the difference between the Nobel Prize Committee being politically independent and the Committee being unbiased. According to its statutes, the Committee is independent. The Norwegian Government or any other agency for that matter does not have any right to interfere with the Committee's decisions. This independence is important, but it is very difficult to understand in China where "associations, of all types, need to be officially registered (Unger and Chan 2008:55). Does the independence of the Nobel Committee mean that it is unbiased? How could it be? Like all human beings its members are influenced by attitudes and general orientations current in the society they are members of. In Norway there are strong feelings of attachment to certain countries as manifested in the individuals or organizations that the committee has not found worthy of the Nobel Peace Prize, e.g. Mahatma Gandhi. More than anybody else Gandhi advocated non-violence as a political weapon, but he used this weapon against a country Norway was closely attached to, namely the United Kingdom. Despite the fact 
that Gandhi used non-violence in an anti-colonial struggle for the Human Rights of the Indian people he was not in his lifetime found worthy by the Nobel Committee. Another example is of course Mordechai Vanunu, the Israeli nuclear technician who revealed details about Israel's nuclear program, and after being kidnapped from Italy by Israeli agents was convicted in a trial behind closed doors to 18 years in prison. He has been nominated to the Nobel Prize several times, but again Israel is a country that many Norwegians feel closely attached to, despite its unwillingness to abide by UN resolutions. If we then look at those who have received the award there are also things to wonder about. The 2009 award to President Obama is incomprehensible to me, no matter how much I admire Obama.

The western bias is even more bizarre when we look at another American who was awarded the Nobel Peace Prize. On 9/11 1973 the democratically elected president in Chile was overthrown and died in a military coup supported by USA. In his report to President Nixon, the architect of the American policy, Henry Kissinger stated: "I recommend, therefore, that you make a decision that we will oppose Allende as strongly as we can and do all we can to keep him from consolidating power” (Lobe, 2004). The same year Kissinger was awarded the Nobel Peace Prize.

Despite the unavoidable cultural and political biases, the Peace Prize Award has a high international reputation and the universal attention attached to the award may either imply honor or shame to the country or Government of the award winner. The 2010 award is in China clearly seen as shaming the Chinese Government.

\section{The Nobel Prize and Human rights}

In its practice the Nobel peace committee has interpreted its mandate in a broad way to include contributions to alleviation of poverty, as well to promotion of Human Rights. The so-called universal Human Rights were formulated in a particular sociocultural and politico-economic context, namely the western world. The formulation focuses on citizens' rights to freedom of speech, movement, and religious practice. China has a wider definition that includes economic and social conditions, and claims that the priority given to specific kinds of rights must be different in countries at different stages of development.

In 1970 The Nobel Peace Prize Committee awarded the Nobel Prize to the agricultural scientist Norman Borlaug for his scientific and practical contribution to increased grain production (The Green revolution). In his acceptance speech Borlaug stated:“The guiding principles of the recipient of the 1969 Nobel Peace Prize, the International Labor Organization, are expressed in its charter words:'Universal and lasting peace can be established only if it is based upon social justice. If you desire peace, cultivate justice.' This sounds magnificent; no one can disagree with this lofty principle. Almost certainly, however, the first essential component of social justice is adequate food for all mankind. Food is the moral right of all who are born into this world. Yet today fifty percent of the world's population goes hungry. Without food, man can live at most but a few weeks; without it, all other components of social justice are meaningless. Therefore I feel that the aforementioned guiding principle must be modified to read: If you desire peace, cultivate justice, but at the same time cultivate the fields to produce more bread; otherwise there will be no peace” (Borlaug, 1970).

However poverty alleviation is not only a matter of technical innovations but also of economic policy. Over the last 30 years China has made unprecedented contributions to bring several hundred millions of its citizens out of extreme poverty. I don't think it is too far-fetched to say that the Chinese Government's contribution to material welfare of its citizens is comparable to Borlaug's contribution to food production. For 12 years I have visited with my Chinese and Norwegian students some of the most isolated rural areas in Yunnan, and have seen the incredible improvements in welfare that have taken place from year to year.

In my opinion, the establishment of legal rules and institutions that promote cultivation of Human Rights must be seen in a wider context of socio-economic development. Here I will refer to the famous American jurist Oliver Wendell Holmes (Associate Justice of the Supreme Court of the United States from 1902 to 1932): "The life of the law has not been logic; it has been experience. The law embodies the story of a nation's development through many 
centuries, and it cannot be dealt with as if it contained only the axioms and corollaries of a book of mathematics" (Wendell Holmes: 1881 (reprint 1991:1). I shall take the historical experiences of China as a vantage point for reflecting on the Chinese reaction to the Nobel Peace Prize for 2010. Historical experiences are what are memorized in cultural expressions like literature and heroic tales, ceremonies and monuments, and informal discussions. In every country such expressions are part of cultural traditions that serve not only to foster national identity, but also to give people conceptual frames for interpretation of and reaction to the complex world of events they are exposed to. The politics of historical memories are critical and actors and agencies (e.g. Chinese Communist Party) may have very different interests in the historical images that are publicly projected. In China as well as in USA and Norway what we learn about the past in school books are loaded with implicit propaganda. There are of course great differences with regard to how freely these historical images can be criticized. Although most people may not have a very clear knowledge of past events, the important thing is that they have the potential to express politically charged meanings for use in political discourse.

\section{Salient events in China's recent history}

Different countries have gone through different historical experiences and have harvested different experiences of felt necessities, and the kind of legal rules that they consider morally justifiable to deal with felt needs as they perceive and conceptualize them. What are the salient historical experiences that are memorized in Chinese cultural traditions?

The revolution in 1911 ended the Chinese empire that for more than 2000 years had been the greatest state on earth. Ideologically the continuity of the Chinese state was based on Confucian ideas about the right social order. A central point in Confucius' teachings is to establish micro-macro congruence between the family domain and the ruler's domain. Filial piety was the highest virtue and was the ideological foundation of the patriarchal family system as well as the empire. This ideology is the basis for harmony in society, but this kind of harmony is based on acceptance of hierarchy, and must not be confused with western notions of harmony as implying relations between equal partners. There was thus a continuum in religious practice and ethical beliefs from the individual level to the level of the emperor.

An important factor in the fall of the Empire was the experience of humiliations during the nineteenth century when the Chinese government was forced to grant western imperialist powers extensive extraterritorial rights. Furthermore the unity of the state has for hundred of years also been threatened by local movements challenging the legitimacy of the existing governments (Haaland, 2010).

With the establishment of the Republic of China the republican government tried to introduce a new ideology, socialism, to legitimize its rule. However, the new state was not able to create order, and internal chaos continued under the republic. After 40 years of war-lordism a functioning state was established in 1949 when the Communist Party led by Mao Ze Dong came to power. When I talk with elderly people in Yunnan about Mao, it is his contribution to bring the countryside out of the chaotic world dominated by rivaling warlords they emphasize. This legacy is an important factor serving to legitimate Communist Party rule, at least in rural areas. With the victory of the Chinese Communist Party, Chairman Mao, saw it as a major point in his cultural policy to break down the ideology that underpinned the patriarchal family because it was the same ideological premises that legitimated the Empire. He thus explicitly stated that he was against Confucius, and instead articulated ideas from the legal school of another ancient philosopher, Han Feize who advocated the view that policy should be oriented towards the future instead of seeking guidance in the example of the 3000-year-old Zhou civilization. However, after Mao the legacy of Confucianism has steadily increased.

\section{The achievements of Modern China over the last 60 years}

In order to have some understanding of the politico-economic developments that have taken place since the Communist Party took power in 1949 one should try to see them in the light of the 


\section{$90 \mid$ Gunnar Haaland}

historical experiences China had gone through over the last 100 years. These experiences have had tremendous effects on how the new government has perceived various felt necessities, and on the policies (including legal rules) that it has found appropriate in order to tackle these needs under the adverse circumstances it has faced:

i) The need to establish some kind of social order after 40 years of chaotic war-lordism.

ii) A rapidly growing population of more than half a billion people (1949)

iii) A backward and stagnant economy

iv) Difficult relations to other great powers on the international scene

iv) Internal unrest

v) Discredited traditional politically legitimating formula and untried modern ideologies.

The tasks involved in finding solutions to these necessities have been formidable, and so have the risks of making mistakes of gigantic proportions. Since 1949 different solutions were tried, some of them with disastrous results, e.g. the Great Leap Forward (1958-61), and the Cultural Revolution. However with the Opening Up policy from 1979 the trend has been rather consistent. This began with the rural reform that by 1983 resulted in dismantling rural collectivities and privatization of collective property except farmland.

When I in 2009 on Chinese TV watched the sixtieth year celebration for the establishment of the Peoples' Republic of China I only saw one person (Hu Jintao) with a Mao suit, all the others had western suits. I did not hear anything about Marxist class struggle, only Confucian harmony ideology with its implied hierarchical principles. This has somehow turned conventional Marxism upside down: The infrastructure is increasingly based on a capitalist mode of production; the political structure is controlled by the Communist party; while the ideological superstructure legitimizing the whole thing increasingly draws inspiration from Confucius' moral teachings. Recently a very interesting attempt to construct a symbolic bridge between the legacy of the revolutionary hero, Mao Ze Dong, and the legacy of Confucius, is manifested in the erection of 9.5 meter tall statue of Confucius in front of the National Museum in Tian'anmen Square where it faces at similar giant statue of Mao in front of his Memorial Hall. The construction of the Confucius statue on the main stage of China's political theater, Tian'anmen Square, adds an intriguing dimension to the importance of cultural politics in cementing social cohesion in a country that is going through dramatic politico-economic transformations with great crack-producing potential.

This certainly involves a dramatic change with unforeseen consequences and with many possible pitfalls. A most dramatic change has been the transfer of State-Owned Enterprises (SOE) to private ownership. According to official statistics, the state-owned economy accounts for $35 \%$ of the GDP, most importantly contributed by industries such as telecom, banking, petroleum, and electricity, which are all controlled by the government. The real estate economy, which is a major GDP pusher, is also largely a government-run-business.

The government percentage is however heavily undervalued, because companies with shares controlled by the government are not regarded as part of the state-owned economy. One of the most problematic consequences of the transfer is what one of the participants in the Chinese debate, He Qinglian in her 'Book China's Pitfall’ (reviewed by Liu Binyan and Perry Link, 1998) calls “marketization of power” (He Qinglian, 1998). According to her, a weakening of the state may be just as much a threat to an open society as it is to an authoritarian state. In her view the growth of private economic capital has been closely connected to accumulation of political capital in the sense that bureaucrats play an essential role in the allocation of licenses and contracts and that economic entrepreneurs try to influence favorable decisions through bribes (fubai). In China this interdependence between economic and political capital is influenced by the notorious practice of guanxi-social connections established through gift giving and reciprocal exchanges of favors that traditionally have been loaded with moral obligations. The difference between fulfilling a moral obligation (renqing) and corruption (fubai) is however a tricky one. Today companies-local and foreign-spend heavily on establishing and maintaining guanxi relations to 


\section{2 | Gunnar Haaland}

officials who wield influence. The risks involved in playing the guanxi game were however clearly outlined in a speech by Deng Xiaoping at the third plenary session of the central advisory committee of the communist party of China, October 22 1984, "Some governmental functionaries have committed economic crimes so serious that they caused state financial losses amounting to as much as several million, or even ten million Yuan. Why can't they be sentenced to death in accordance with the criminal law”? (Ikels, 1996:39).

I expect the commercialization of power and the rise of new classes will create tensions in Chinese politics both inside the Party as well as on the outside. The question is where will the tensions take China? This should not be discussed in the abstract, but in the relations to the socio-cultural realities in China and the way they are perceived by actors differently positioned economically and politically.

\section{The Prospect for development of civil society}

When I read Habermas (1989:32) about the emergence of civil society in England and France I am somehow optimistic "----the coffee houses in their golden age between 1680 and 1730 and the salons in the period between regency and revolution----were centers of criticism-literary at first, then also political-in which began to emerge, between aristocratic society and bourgeois intellectuals, a certain parity of the educated.”

The phenomenal growth in coastal towns and cities in China since the 1990s of teahouses, coffee shops, internet cafes, karaoke bars, pubs, private salons and private theaters (and to my despair McDonalds) has opened up a variety of spaces for public debate. If Habermas is right that pubs and coffee houses were the real force behind the emergence of British and French civil society, I am somehow optimistic about the future trends in development of civil society in China.

From my visits with Chinese and Norwegian students to bars and restaurants in Shanghai and Kunming I have a feeling that such places are important forums where different positions in the ongoing debate on political reform in China are articulated. Most importantly in recent years the Internet has opened a new space for public discussion despite the government's attempt to censorship (The Great Chinese Firewall). As far as I can judge from discussions in such places the debate is surprisingly open and the points of view even when they are brought into official media, differ sharply in evaluations of political and economic aspects. They certainly don't reflect any consensus about the future direction of China.

I expect that the many new public sites and spaces may play a very important role in the emergence of Chinese civil society. Spaces for public discussion of important social and politico-economic issues constitute an important dimension of civil society, but as I understand it the concept of 'civil society' means the existence of an intermediary sphere of autonomous "organizations separate from the state, the market and the family, that brings citizens together for diverse forms of social action and interaction (Watson, 2008:14). With the relaxation of direct Party controls during the opening-up policy, the government needed mechanisms to bridge the gap between the state and its citizens. However, in China all associations must be officially registered and/or are frequently initiated by the government, and each association is set up as the representative of specific constituencies from religious affairs to technological associations. (The fascist government in Italy in the 1930s initially set up such corporatist associations). Harmony is appealed to in corporatist systems like it is in modern Communist China today. This kind of harmony involves top-down control from the Party who knows the 'true' interests of society. It is likely that tensions will emerge in relation to the reform debates taking place in the many new spaces for public expressions not only in 'teahouses' but to some extent also in various media, not least the Internet.

Cheng Li (2000) has drawn attention to an important point that is critically debated in China, namely whether the growing pains of increased inequality that follows from Deng Xiaoping's reforms is just a short-term consequence that necessarily accompanies institutional change, or whether it leads the country into deepening pitfalls. Deng Xiaoping's market-based policy of "letting a small 


\section{$94 \mid$ Gunnar Haaland}

number people getting rich first” implied initial growing pains of inequality, but over time a higher standard of living would spread throughout society. However scholars like He Qinglian has argued that the reform policy leads to deepening pitfalls with growing economic inequalities, social injustice, unfair competition, and high unemployment. This theme is a critical issue in China today. A commonly used measure of inequality of wealth is the Gini coefficient-a statistical expression of income distribution in a country that may range between 0 (complete equality; every person receives the same share of the country's total income) and 1 (complete inequality; one person receives 100\% of the total income and the rest of the population receives 0\%). In China the Gini coefficient has increased from 0.16 before the Opening policy was introduced to 0.47 at present. It has passed 0.4--the warning line and is on the same level as in USA and higher than all other developed countries. Lu Caizhen has raised some critical points about Deng Xiaoping’s policy: “In 1985 Deng Xiaoping spoke of 'allowing some people to get rich first'. Since then, economic development has been emphasized. After 1990, farmers began moving to the cities to get work. More and more farmers migrated to the urban areas for odd jobs or to set up a business. Rich people appeared while others remained in poverty. Polarization emerged in society. Gradually, people' attitudes towards the rich and poor changed. Now the rich are thought as capable and the poor as incapable. Conflicts between the poor and the rich are increasing." (Lu Caizhen, 2009:109).

Since the opening up policy China's GDP has grown by an average of $9.5 \%$ a year. With the introduction of the household responsibility system this growth also simulated growth in the agricultural sector involving more production of cash crops and not just grain. However from 1984 the contribution of the agricultural sector to GDP has fallen from $40 \%$ to $16 \%$. The most spectacular development has since then taken place in the industrial sector. The relationship between the agricultural sector and the industrial sector seems to have dualistic features because a substantial part of the industrial work force consists of the so-called 'floating population' that in 2009 was estimated to 211 million (Xinhua, 2010). The floating population consists of migrants from rural areas that do not have an urban hokou (household registration).
According to the hokou system, individuals were categorized as a "rural" or "urban" workers. People who worked outside their hokou area of registration would not qualify for grain rations, employerprovided housing, or health care and educational facilities.

The consequence of this has been development of an economic structure similar to the dual economies found in many countries dominated by colonial powers. As Geertz (1956) has pointed out the central concern in these policies was to bring people's products into the international economy, but not the people themselves. The strategy was to make pre-capitalist cultivators produce crops for capitalist agro-industries, or by stimulating members of precapitalist family farms to provide cheap labour for capitalist enterprises. After Deng Xiaoping's reforms there has been a flow of migrants from rural to urban areas in search of employment in the urban sector, but without enjoying the same access to the public services like people with an urban hokou. A substantial part of the industrial labour force has thus been reproduced in the agricultural areas, and it is to thee areas labour migrants retire after having spent a large part of their productive lives in urban areas. The implications for this was to reduce the governments expenses for social services, and to keep a low wage level in the industrial sector since the labour force was reproduced in the rural sector. The low labour costs are one factor in the phenomenal success of the industrial sector in particular since the profit of this sector depends on exports. After China in 2001 joined the WTO, trade has increased from under $10 \%$ to $64 \%$ of GDP. The inequalities created in the dual economy constitute a serious pitfall in modern China.

The social tensions created in China's dual economy are linked to the capitalization of power that accompanied Deng's institutional changes. If He Qinglian is right these changes have implied that actual competition takes place in the political field, not in the economic field. If so, this is a competition where party members are in a privileged position allowing them to convert political capital to economic capital and vice versa particularly through clever guanxi practice. After Deng Xiaoping's encouragement in 1992 to xiahai (jump into the sea of private business) a large number of high-ranking cadres established themselves as private 
entrepreneurs but most importantly as managers of so-called Town and Village Enterprises (TVEs).

However others like Pei Minxin (1994) and Tony Saich (1994) argue that the trend is towards a pluralist society and point to the growth of an entrepreneurial class unconnected to the Party elite. This growing middle class is a new force in China that can erode the legitimacy of the authoritarian regime. During the 1980s there was a growth of so-called getihu (individual households) of young people from humble backgrounds who made successful careers as retail sellers, becoming the first group of rich people in the cities. Yan Yunxiang comments: "Because of their conspicuous spending habits, along with their somewhat negative personal backgrounds, such people became targets of criticism by the elite strata and the focus of public envy of almost all of society" (2009:225). To call such people 'nouveau riche' just reflects the old Chinese tradition of looking down upon merchants. Traditional Confucianism did not favour economic enterprise and merchants were subordinated to the mandarins (scholar-officials) and were even considered below peasants. Fei Xiao Tong (1953:62) has expressed Confucius' legitimating idea for mandarin domination as follows:

"The people must work on the land, but those at the top need only acquire and keep the respect of the people through upholding the $l i$-justice and faith. The man who knows about the norms of conduct need not work for his living”.

He Qinglian and Wang Lixiong have argued that the market economy produced a culture of greed and corruption that served to break down people's ideas and moral rules. This will according to them be the source of a future social crisis in China. Against this others like Saich (1994) have argued that in the cultural arena, "political and economic decentralization, transnational mobility, economic diversity, and consumerism have led to a renewed sense of locality, individuality and diversity" (Cheng Li, 2000). The new developments is not just a matter of money, it is also a matter of better quality of life, of new choices, of new ways of thinking. These issues are discussed in the new spaces for debate (teahouses as well as media) and are likely to have a significant effect on the

\section{6 | Gunnar Haaland}

development of civil society, and may serve to challenge Party control. As China is increasingly drawn into the network of global cultural participation these tensions will constitute a critical political problem.

\section{The Nobel Prize Award: rallying solidarity with Party rule or stimulating growth of civil liberties.}

When the International Criminal Court (ICC) in 2009 issued an arrest warrant for the Sudanese President Omar al-Bashir on accounts of war crimes and crimes against humanity, this was in Sudan considered an insult to the country even among people critical of his rule and served to rally support behind him. Clearly the Chinese government sees the Nobel Prize Award as an insult to their country. The questions are whether the general public sees it as another unjust foreign snub to their pride and whether they see as it as a welcome support for development of a more open civil society. The extent to which different opinions are clearly expressed is not only influenced by government restrictions but also by participants' opportunistic considerations of their stakes in the existing systems compared to what gains they may harvest from liberalization.

In China various voices are expressed, and they certainly are more informative and nuanced than Glen Beck on Fox TV (one of most popular networks in America) as well as other western media. In western countries we may be free to speak up to a point (The US Government's reaction to Wikileak's investigative journalism indicates where this point is), but the opportunity to influence public opinion through "free speech" is not equal, but is significantly a matter of ability to convert economic capital into media dominance. The dominant position of Robert Murdoch in the American media world may represent a dangerous change from the "one person-one vote" that democratic ideology claims, to a "one dollar-one vote" that more critical commentators fear.

My experiences from the Chinese debates make me feel that the comparison of this year's award with the 1935 award to Carl Von Ossietzky is misplaced and taken out of historical context (In 1931 during the time of a democratically elected German Government 
Ossietzky was sentenced for high treason for revealing that Germany was rebuilding the air-force against the Versailles treaty, a verdict that was upheld by the Federal Court of Justice in 1992). In the thirties the Nazi government was restricting Human Rights, and Fascism had an appeal in many European countries including Norway. The prize therefore had an important symbolic effect. As I understand it, China today is not undergoing a similar process of restrictions of Human Rights that we saw in Nazi Germany. On the contrary I see more open debates every year I visit China albeit with periodic setbacks. What I don't like is that the prize may be seen as another example of western double standards in the way the Committee evaluate the achievements and failures of western countries versus those of China. Think about the reactions in USA if Bradley Manning (the US soldier charged with the disclosure of classified information publicized on Wikileak's website, and showing among other things atrocities committed by US armed forces) had been awarded Nobel Peace Prize-his condition in prison is according to reports certainly not more human than Liu Xiao Bo's condition in China.

\section{Conclusion}

China has gone a long way since 1949. In the words of the Hungarian-American financier Georg Soros, "today China has not only a more vigorous economy, but actually a better functioning government than the United States" (Soros, 2010). However I am far from certain about the stability of the government and how it manages to cope with new tensions, not least those that are caused by the increasing income gap created by the way guanxi practices lead to Capitalization of Power, particularly if new independent entrepreneurs are drawn into guanxi relations with party members, solidifying the "Party - Commercial Complex", by connecting it to the existing Educational Communist Elite Complex". On the one hand these complexes serve to reduce potential conflicts between the interests of bureaucrats and entrepreneurs, but on the other hand it creates a gap between the winners and losers in the guanxi game.

On the individual level there has according to Yunxiang Yan (2009) been a remarkable growth of individualization, partly a consequence of the growing importance of the market economy, but also as a consequence of the party-state's institutional changes that favored the interests of youth and women. This "managed individualization" has to a large extent "been internalized by individuals in the third decade of reform (1998-2008) and even the most free-spirited youth knew that they could more or less do what they wanted in their personal lives, but that they had to remain within the political boundaries drawn by the party-state---As Chu Shu, a high-school-dropout-turned-young and the hottest youth idol in 2004, explained to a Western journalist: "Our concept of freedom is different from the west". We want the physical freedom to travel where we want, work where we want, have the friends we want. But right now we can't be so concerned with spiritual freedom” (Yan, 2009: xxxi).

There is a time and place for everything. Was it wise of the Nobel Prize committee to select a dissident articulating Human Rights as the award winner, and was 2010 the right time to give the award? I have grave doubts and am tempted to give the same answer as the late premier Chou En Lai did when he was asked what he thought about the French Revolution: "It is still to early to tell."

\section{References}

Borlaug, N. (1970). Nobel Lecture, December 11, 1970. Nobelprize.Org, assessed 11 August 2011 $<$ http://nobelprize.org/nobel prizes/peace/laureates/1970/b orlaug-lecture.html $>$ Charter 08 2008, accessed 11 August 2011, <http://www.hrichina.org/content/238>

Cheng $\mathrm{Li}$ (2000). Promises and Pitfalls of Reform: New Thinking in Post-Deng China. China Briefing 2000. The continuing transformation (ed: Tyrene White). London: An East Gate Book.

Fei Xiao Tung (Hsiao-tung Fei 1953). China's Gentry. Phoenix: Chicago University Press Books. Chicago

Geertz, C. (1956). Capital-intensive agriculture in a peasant society: A case study. Social Research: an international quarterly of political and social science, vol 23. No 2 pp 433-449 


\section{0 | Gunnar Haaland}

Haaland, G. (2010). Reflections on Contrasting Views on Themes in Chinese Civilization. Dhaulagiri Journal of Sociology and Anthropology Vol. 4, 2010

Habermas, J (1989). The Structural Transformation of the Public Sphere. Cambridge:Polity Press.

He Qinglian (1998). Zhongguo de xianjing (China's Pitfall). Hong Kong Mingjing chubanshe.

Ikels, C. (1996). The Return of the God of Wealth. Standford: Stanford University Press.

Liu Binyan and Perry Link (1998). A Great Leap Backward ? New York Review of Books. Vol. 45, no 15 (October 8, 1998).

Lobe, J. (2004). Kissinger Document Shows Pre-Emption in Practice. Common Dreams.Org, accessed 11 August 2011, <http://www.commondreams.org/headlines04/0205$\underline{07 . h t m>}$

Minni Chan (2011). 'Wen in renewed plea for wider political reforms’, South China Morning Post, 29 April 2011, accessed11August 2011, $<$ http://topics.scmp.com/news/china-news-

watch/article/Wen-in-renewed-plea-for-wider-politicalreforms>

Pei Minxin (1994). From Reform to Revolution: The Demise of Communism in China and Soviet Union. Cambridge: Harward University press

Saich, T (1994). The Search for Civil Society and Democracy in China. Current History.

Soros, G.' Business Insider Nov. 16, 2010, accessed 11 August 2011, <http:/www.businessinsider.com/georgesoros-today-china-has-not-only-a-more-vigorous-economybut-actually-a-better-functioning-government-than-t-2010$11>$

Unger, J, and Chan, A (2008). Associations in a Bind: The Emergence of Political Corporations. Associations and Chinese State. Contested Spaces. (ed: Jonathan Unger) M.E. Sharp. London: An East Gate Book.

Watson, A, (2008). Civil Society in a Transitional State: The Rise of Associations in China. Associations and the Chinese State: Contested Spaces. (ed: Jonathan Unger) M.E. Sharp. London: An East Gate Book

Wendell Holmes, O.: The common law. (1881 reprinted1991). New

\section{York: Dover Publications}

Yan Yunxiang (2009). The Individualization of Chinese Society. Oxford: London School of Economics Monographs on Social Anthropology. Vol. 77. Berg. 